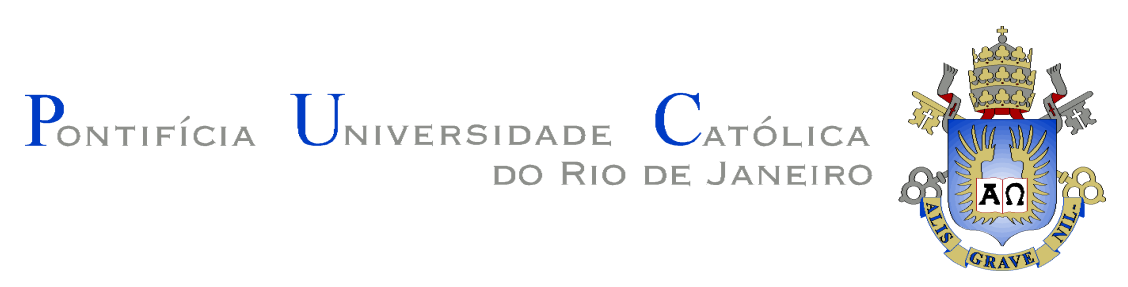

Gilcemar Hohemberger

\author{
A fé cristã como possibilidade de uma \\ verdadeira existência humana, \\ segundo Joseph Ratzinger
}

Dissertação de Mestrado

Dissertação apresentada ao Programa de Pósgraduação em Teologia da PUC-Rio como requisito parcial para obtenção do título de Mestre em Teologia.

Orientador: Profo Mário de França Miranda

Rio de Janeiro Abril de 2013 


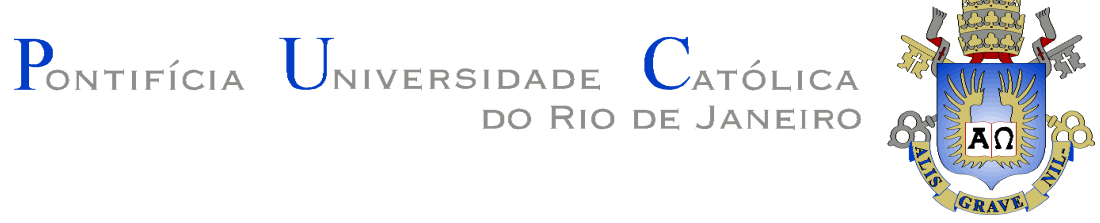

Gilcemar Hohemberger

\begin{abstract}
A fé cristã como possibilidade de uma verdadeira existência humana, segundo Joseph Ratzinger
\end{abstract}

Dissertação apresentada como requisito parcial para obtenção do grau de Mestre pelo Programa de Pós-graduação em Teologia do Departamento de Teologia do Centro de Teologia e Ciências Humanas da PUC-Rio. Aprovada pela Comissão Examinadora abaixo assinada.

\author{
Prof. Mario de França Miranda \\ Orientador \\ Departamento de Teologia - PUC-Rio
}

Prof. Luís Corrêa Lima

Departamento de Teologia - PUC-Rio

Prof. Paulo Cezar Costa

Departamento de Teologia - PUC-Rio

Profa. Denise Berruezo Portinari Coordenadora Setorial de Pós-Graduação e Pesquisa do Centro de Teologia e Ciências Humanas - PUC-Rio

Rio de Janeiro, 01 de abril de 2013 
Todos os direitos reservados. É proibida a reprodução total ou parcial do trabalho sem a autorização da universidade, do autor e do orientador.

\section{Gilcemar Hohemberger}

Graduou-se em Filosofia na FAPAS (Faculdade Palotina) em 2006. Cursou Teologia no Instituto de Filosofia e Teologia do Seminário São José de Niterói em 2010. Em 2012 concluiu o curso de Pós-Graduação Latu Sensu em Filosofia pela Universidade Gama Filho. Participou de diversos congressos na área da Filosofia e Teologia. É autor de vários artigos e livros sobre temas de Teologia e Filosofia.

Ficha Catalográfica

Hohemberger, Gilcemar

A fé cristã como possibilidade de uma verdadeira existência humana, segundo Joseph Ratzinger / Gilcemar Hohemberger; orientador: Mário de França Miranda. - 2013. 145 f.; $29,7 \mathrm{~cm}$

Dissertação (mestrado) - Pontifícia Universidade Católica do Rio de Janeiro, Departamento de Teologia, 2013.

Inclui bibliografia

1. Teologia - Teses. 2. Ratzinger, Joseph. 3. Fé cristã. 4. Verdade. 5. Razão. 6. Deus. 7. Ser humano. 8. Modernidade. I. Miranda, Mário de França. II. Pontifícia Universidade Católica do Rio de Janeiro. Departamento de Teologia. III. Título.

CDD: 200 


\section{Agradecimentos}

A Deus, pelo dom da fé e pelo seu amor infinito, pela abundância dos dons derramados e pelo chamado ao ministério teológico, mas principalmente.

Aos meus pais, Gildo e Margarete, que me educaram na fé e despertaram o amor a Deus e a sua Igreja, que me ensinaram pelo testemunho os valores cristãos. Aos meus irmãos, Giciéli (Sandro e Camilly) e Diones, pessoas especiais que me ensinaram o valor da partilha, do amor ao próximo e da fidelidade à fé recebida. Em especial, agradeço a minha noiva, Ana Letícia, pela paciência, afeto, apoio e amor dispensado ao longo do Mestrado, e seus pais (Laísa e Luís Claudio).

De forma muito singular, minha gratidão ao Prof. Dr. Mario de França Miranda, orientador disponível, seguro, compreensivo e com ampla visão teológica, pela inestimável ajuda em todas as etapas da elaboração desse trabalho e pelo exemplo de fé e humildade.

À CAPES (Coordenação de Aperfeiçoamento de Pessoal de Nível Superior) e à PUCRio pelo incentivo financeiro e por todos os auxílios concedidos. De modo especial à coordenação da Pós-Graduação em Teologia e aos funcionários, de modo especial ao Sérgio, pelo atendimento sempre profissional e cordial.

Aos professores da PUC-Rio, mestres sérios e seguros, em especial Prof ${ }^{a}$. Ana Maria Tepedino que, ao longo do percurso, foi uma grande motivadora pessoal nos estudos teológicos. Gratidão também ao Prof. Dr. Dom Paulo Cezar Costa, pelo imenso apoio.

Aos professores que participaram da Comissão Examinadora.

À Dom Ivo Loscheider (in memorian), bispo e pastor, grande inspirador, que me acolheu como filho e estimulou a prosseguir com os estudos teológicos.

À Dom Frei Alano Maria Penna, OP, que me acolheu na Arquidiocese de Niterói e despertou um profundo interesse pela obra de Joseph Ratzinger.

À Sônia (in memorian) e Rosangela, mulheres que Deus colocou no meu caminho, que me acolheram nos momentos mais difíceis e partilharam um pouquinho do seu amor. Gratidão eterna. 


\section{Resumo}

Hohemberger, Gilcemar; Miranda, Mario de França. A fé cristã como possibilidade de uma verdadeira existência humana, segundo Joseph Ratzinger. Rio de Janeiro, 2013. 145 p. Dissertação de Mestrado Departamento de Teologia, Pontifícia Universidade Católica do Rio de Janeiro.

A fé cristã como possibilidade de uma verdadeira existência humana, busca fazer uma leitura do pensamento teológico de Joseph Ratzinger, sistematizando a temática da fé cristã e demonstrando a força e vitalidade que a tornam possibilidade de uma verdadeira existência humana nos dias de hoje. O cenário que faz fundo a este estudo é a questão da verdade e a crise da fé no contexto moderno. Diante da atual conjuntura cultural e teológica da fé cristã, o cristianismo encontra-se perante um verdadeiro dilema: a compreensão moderna de realidade, na qual o alcance cognoscitivo se limita ao sensível, ao que é fenomênico, onde a única realidade existente é a matéria, estabelecendo assim um reinado do factível e o predomínio de uma filosofia: o relativismo. A fé cristã, no entanto, vai além daquilo que a pura razão é capaz de reconhecer, vai ao encontro de Cristo, do logos, do sentido, da própria verdade. O ser humano não pode ser sustentado somente pelo que é visível e tangível, pelo mensurável, por isso a fé o impele a uma abertura decisiva para o Logos. Portanto, a fé cristã não é um sistema, uma ideia, uma entrega cega ao irracional, mas pertence ao âmbito da verdade, pois é a opção para a prioridade da razão e do racional. Crer é razoável. Assim, é possível compreender a função humanizadora da fé cristã e sua estrutura pessoal: a essência da fé cristã consiste em aceitar e viver a existência como relacionalidade, cuja fórmula central é "Creio em ti" e não "Creio em algo". Nessa relação com Deus Pessoa se instaura a primazia do amor: ser cristão é humanizar-se pelo amor. Um Deus-Amor que atua de modo transtemporal e translocalmente, promovendo um encontro da fé com as culturas, não para privá-las 
de algo, antes para constituir um estímulo à busca da plenitude da verdade. Esta síntese do pensamento de Ratzinger sobre a fé cristã quer afirmar que, somente em Deus, o ser humano alcança o sentido da vida, uma real e verdadeira existência humana.

\section{Palavras-chave}

Fé cristã; Verdade; Razão; Deus; Ser humano; Modernidade; Joseph Ratzinger 


\section{Abstract}

Hohemberger, Gilcemar; Miranda, Mario de França (Advisor). The Christian faith as a possibility of a real human existence, according to Joseph Ratzinger. Rio de Janeiro, 2013. 145p. MSc. Dissertation - Departamento de Teologia, Pontifícia Universidade Católica do Rio de Janeiro.

The Christian faith as a possibility of a real human existence, seeks to make a reading of the theological thought of Joseph Ratzinger, systematizing the set of themes of Christian faith and demonstrating the strength and vitality that make it, currently, a possibility of human existence. The scenario that makes background to this study is the question of truth and the crisis of faith in the modern context. Given the current cultural and theological circumstances of the Christian faith, Christianity faces a real dilemma: the modern understanding of reality, in which the cognoscitive scope is limited to sensitive, phenomenal, where the only reality that exists is the matter establishing, thus, a reign of feasible and the prevalence of a philosophy: relativism. The Christian faith, however, goes beyond what pure reason is capable of recognizing, towards Christ, the logos, the sense, the truth itself. The human being can not be sustained only by what is visible, tangible and measurable, so faith impels a person to a decisive opening to the Logos. Therefore, the Christian faith is not a system, an idea, a blind surrender to the irrational, but it belongs to the realm of truth, it is the choice for the priority of reason and rational. Believing is reasonable. Thus, it is possible to understand the humanizing function of the Christian faith and its personal structure: the essence of the Christian faith is to accept and live life as relationality, whose core formula is "I believe in You" and not "I believe in something." In this relationship with God Person is established the primacy of love: being a Christian is to humanize by love. A God-Love that acts so transtemporal and trans-local, promoting an encounter of faith with cultures, not to deprive them of something, rather to provide a stimulus to search for the fullness of truth. This 
synthesis of thought of Ratzinger about the Christian faith wants to assert that only in God, the human being attains the meaning of life, a real and true human existence.

\section{Keywords}

Christian Faith; Truth; Reason; God; Human being; Modernity; Joseph Ratzinger 


\section{Sumário}

1 - Introdução 11

2 - Introdução à vida e teologia de Joseph Ratzinger 16

2.1 - Breve introdução biográfica 16

2.2 - Traços do perfil teológico 23

3 - O contexto cultural e teológico da Fé Cristã segundo Joseph Ratzinger $\quad 27$

3.1 - A situação do ser humano diante da questão de Deus 27

3.2 - O dilema da fé no mundo de hoje 30

3.2.1 - O dilema da fé em relação ao futuro 32

3.2.2 - O dilema da fé no confronto com o conhecimento 36

3.2.3 - O dilema da fé na relação com a filosofia 39

3.3 - O problema da verdade e a ditadura do relativismo 42

3.3.1 - A inevitabilidade da questão da verdade $\quad 43$

3.3.2 - A pretensão da verdade posta em dúvida 45

3.3.3- A gênese do problema da verdade e da ditadura do relativismo 50

3.3.4 - O relativismo: filosofia dominante 56

3.4 - À guisa de conclusão: a verdade como questão essencial da fé cristã $\quad 60$

4 - O significado da Fé Cristã segundo Joseph Ratzinger 62

4.1 - Em busca de uma definição da essência da fé 63

4.2 - Fé enquanto ato de firmar-se e de entender 64

4.3 - Crença e existência: a fé como atitude humana fundamental 68

4.4 - A razão da fé $\quad 74$

4.4.1 - Crer é razoável 75

4.4.2 - Reciprocidade de inteligência, vontade e sentimento, na unidade do crer 77

4.4.3 - Dimensão pessoal da fé $\quad 79$

4.5 - A forma eclesial da fé $\quad 80$

4.6 - Estruturas da Fé Cristã: elementos essenciais de uma visão de conjunto da fé cristã 88

4.7 - À guisa de conclusão: a verdade como questão essencial da fé cristã $\quad 94$ 
5 - A humanização da vida pela fé: elementos fundamentais da profissão de fé segundo Joseph Ratzinger $\quad 98$

5.1 - O Deus pessoal da fé cristã 98

5.1.1 - A origem cristã do conceito de Pessoa 99

5.1.2 - A idéia bíblica de Deus como Pessoa e relacionalidade 102

5.1.3 - A pessoa como relação: a instauração da humanização 109

5.2 - Cristo, o "último homem", fator de humanização 112

5.3 - O primado do Amor: a vitalidade da fé cristã 115

5.3.1 - A inseparabilidade fé-amor no cristianismo 116

$\begin{array}{ll}\text { 5.3.2 - A abertura universal da fé cristã } & 120\end{array}$

5.4 - O encontro entre a fé cristã e as culturas 122

5.4.1 - Definição do termo cultura 124

5.4.2 - Inculturação e interculturalidade: definição e distinção 127

5.4.3 - Sobre a relação da fé cristã com as culturas 128

5.5 - À guisa de Conclusão. Crer no mundo de hoje: a possibilidade

de uma verdadeira existência humana 133

6 - Considerações Finais 137

7 - Referências Bibliográficas 141 